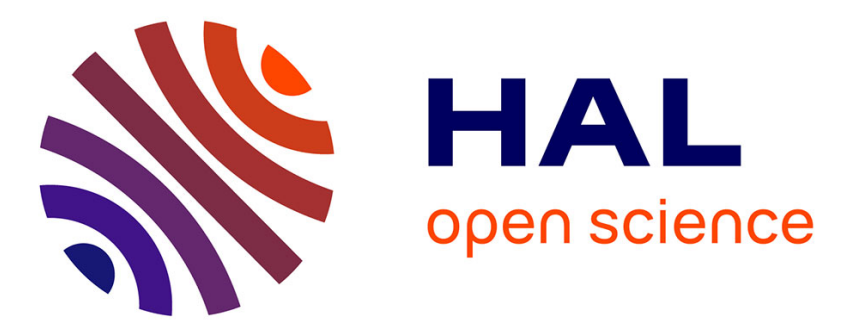

\title{
Evidence that neurites in human epiretinal membranes express melanopsin, calretinin, rod opsin and neurofilament protein
}

Sarit y Lesnik Oberstein, Geoffrey P Lewis, Thomas Dutra, Steven Fisher

\section{- To cite this version:}

Sarit y Lesnik Oberstein, Geoffrey P Lewis, Thomas Dutra, Steven Fisher. Evidence that neurites in human epiretinal membranes express melanopsin, calretinin, rod opsin and neurofilament protein. British Journal of Ophthalmology, 2010, 95 (2), pp.266. 10.1136/bjo.2010.180679 . hal-00587972

\section{HAL Id: hal-00587972 \\ https://hal.science/hal-00587972}

Submitted on 22 Apr 2011

HAL is a multi-disciplinary open access archive for the deposit and dissemination of scientific research documents, whether they are published or not. The documents may come from teaching and research institutions in France or abroad, or from public or private research centers.
L'archive ouverte pluridisciplinaire HAL, est destinée au dépôt et à la diffusion de documents scientifiques de niveau recherche, publiés ou non, émanant des établissements d'enseignement et de recherche français ou étrangers, des laboratoires publics ou privés. 


\title{
Evidence that neurites in human epiretinal membranes express melanopsin, calretinin, rod opsin and neurofilament protein
}

\author{
Sarit Y. Lesnik Oberstein, M.D., Ph.D., Geoffrey P. Lewis, Ph.D., \\ Thomas Dutra, B.S., Steven K. Fisher, Ph.D. \\ The Academic Medical Center Amsterdam, \\ University of Amsterdam, The Netherlands. \\ Neuroscience Research Institute ${ }^{1}$ and Dept. MCD Biology, ${ }^{2}$ \\ University of California Santa Barbara, CA, USA. \\ Correspondence: Sarit Y. Lesnik Oberstein \\ Department of Ophthalmology \\ Academic Medical Center \\ Meibergdreef \\ 1100DD Amsterdam \\ The Netherlands \\ S.Y.Lesnikoberstein@amc.uva.nl \\ Ph: +31205669111 \\ FAX:+31205669053
}

Key words: Neurite, epiretinal membrane, rod opsin, melanopsin, calretinin, Müller cell.

Word count: 2500 


\begin{abstract}
Aims: Previously we have identified neurofilament protein containing neurites in human epiretinal membranes (ERMs). The goal of this study was to further characterise these neurites by examining the expression of additional specific proteins in human ERMs and correlate this expression with various retinal disease conditions.
\end{abstract}

Methods: Epiretinal membranes originating from 43 patients with proliferative vitreoretinopathy (PVR), proliferative diabetic retinopathy (PDR), or with no known pathology (idiopathic epiretinal membrane; iERM), were removed during vitrectomy at varying durations after diagnosis and immediately placed in fixative. The membranes were labeled immunohistochemically with different combinations of antibodies to the proteins melanopsin, calretinin, and neurofilament (to identify subclasses of ganglion cells), rod opsin (to identify rod photoreceptors), synaptophysin and SV2 (identifies synaptic vesicles), and vimentin (identifies glial cells).

Results: Anti-melanopsin, -calretinin, -neurofilament, and -rod opsin labeled neurites were routinely observed in the epiretinal membranes. Their presence did not appear to correlate with a specific disease condition or duration of the membrane. Generally neurites were observed in regions of glial cells.

Conclusions: Based on the expression of selected markers for neurites, we show neurite processes in human ERMs of various aetiologies originating from rod photoreceptors and different populations of retinal ganglion cells although there was no obvious correlation with specific disease condition. Also synaptophysin and SV2 labeling was observed associated with all types of neurites indicating the presence of at least one component necessary for synaptic transmission. Our data suggest that the adult human retina retains a 
significant capacity for neuronal remodeling under various disease conditions.

\section{Introduction}

The adult retina has long been considered a relatively static neuronal system with little potential for plasticity. However, it is becoming progressively clear that it can undergo remodeling in various injuries and diseases. The classical response includes glial cell proliferation, hypertrophy and migration, as well as neuronal changes including neurite pruning and, surprisingly, neurite sprouting. These events have been shown to occur in retinal degenerations and dystrophies, ${ }^{1-6}$ diabetes, ${ }^{7,8}$ retinal detachment $(\mathrm{RD}),{ }^{9-13}$ macular pucker, ${ }^{14}$ macular degeneration, ${ }^{15}$ retinitis pigmentosa (RP), ${ }^{16-18}$ and in aged retina. ${ }^{19,20}$ The newly generated neurites appear to originate from every class of retinal neuron including rod and cone photoreceptors, bipolar, amacrine and ganglion cells and these neurites often grow throughout the retina. ${ }^{21,22}$ (for review)

Interestingly, neurite growth does not always stop at the boundaries of the retina. Once subretinal or epiretinal membranes (ERM) form, regardless of the disease condition, neurites are invariably observed. ${ }^{10,12,14,22}$ ERMs have been shown to contain various cell types including glial cells (Müller cells and astrocytes), retinal pigment epithelial cells, fibroblasts and immune cells ${ }^{23-25}$ However, neurites are always found associated with Müller cells, suggesting that these cells are permissive to the growth of neurite processes. $^{12,14}$

Neurites have been found in ERMs removed from patients with the retinal conditions proliferative vitreoretinopathy (PVR), proliferative diabetic retinopathy (PDR) and $\mathrm{RD}^{12}$ in addition to iERMS removed from eyes with no known retinal injury 
or disease. ${ }^{14}$ To date, only anti-neurofilament labeled neurites have been identified in human ERMs. ${ }^{12,14}$ Since neurofilament protein can be expressed by various cell types the goal of this study was to determine more precisely the cells of origin of neurites present in ERMs and correlate their presence with disease condition, using markers to proteins for cell types that have been shown to sprout neurites within the retina. We also used markers to synaptic vesicle proteins to determine if the neurites contained the machinery for synaptic transmission.

We show here that there are distinct neurite populations in the membranes as evidenced by staining with antibodies to the photopigments melanopsin and rod opsin, as well as the calcium binding protein calretinin. In addition, these neurites grow on a bed of glial cells and many contain the synaptic vesicle proteins synaptophysin or SV2.

\section{Materials and Methods}

Human ERMs were collected during 3 port vitrectomy surgery from 43 patients with different types of retinal pathologies including PVR $(n=14)$, PDR $(n=9)$, and iERM $(n=17)$. Three ERMs were also from non-insulin dependent diabetics without neovascular proliferation (NIDDM). One of the PDR membranes was large enough to be divided into 4 pieces and was used for 4 antibody combinations, and one divided into 2 pieces for 2 antibody combinations. The membranes were removed from the eyes at varying durations after diagnosis. The average durations were: 5 weeks for PVR, 12 months for PDR, 8 months for iERM, and 6 months for NIDDM. After removal, the membranes were immediately placed in fixative (4\% paraformaldehyde in $0.1 \mathrm{M}$ sodium cacodylate buffer, $\mathrm{pH}$ 7.4; Electron Microscopy Sciences, Fort Washington, PA) and stored at $4^{\circ} \mathrm{C}$ until used. The surgery was conducted at the Academic Medical Center, Amsterdam, The 
Netherlands. All procedures had institutional research ethics committee approval and adhered to the tenets of the Declaration of Helsinki.

The ERMs were processed whole, without embedding or sectioning. Following fixation the tissue samples were rinsed in phosphate buffer (PBS) and incubated in normal donkey serum (1:20) in PBS, $0.5 \%$ BSA, $0.1 \%$ Triton X-100, and $0.1 \%$ azide (=PBTA) overnight at $4^{\circ} \mathrm{C}$ on a rotator. The following day various combinations of primary antibodies, in PBTA, were added overnight at $4^{\circ} \mathrm{C}$ on a rotator. The antibodies, their concentration, and sources are listed in Table 1. Anti-SV2 was chosen in cases where the combination of primary antibodies did not allow the use of anti-synaptophysin, although both antibodies label synaptic vesicles in the neurite. Following rinsing of the primary antibodies in PBTA, the secondary antibodies conjugated to $\mathrm{Cy} 2, \mathrm{Cy} 3$, or $\mathrm{Cy} 5$, were added together overnight at $4^{\circ} \mathrm{C}$ on a rotator (1:200 in PBTA). In 2 membranes the primary antibodies were omitted and only the secondary antibodies were added as negative controls. On the final day, the samples were rinsed in PBTA and a Hoechst nuclear stain was added at 1:5000 for $10 \mathrm{~min}$. Without rinsing, the samples were then mounted on glass slides using 5\% n-propyl galate in glycerol and viewed on an Olympus FluoView 500 laser scanning confocal microscope (New York, NY). Final images were collected as projections of 5 to 10 images taken at depths of 0.5 micron intervals.

\section{Results}

All membranes showed the presence of neurites as identified by various combinations of antibodies to neurofilament protein, melanopsin, calretinin and rod opsin (Table 2). Many of these proteins were double labeled with antibodies to synaptophysin or SV2, which are both normally present in synaptic vesicles. 
No obvious correlation was observed with the specific antibody labeling of neurites and the disease condition or duration of the ERM before removal.

Anti-neurofilament (NF) staining was observed in all ERMs and in all disease conditions as reported previously (Table 2). ${ }^{12,14}$ The neurofilament labeling pattern appeared as long, thin processes probably single fibers and thicker structures probably representing clusters of fibers (Fig 1A, C-F), or as bulbous structures (Fig. 1A,C). Anti-synaptophysin labeling of vesicles was seen both in association with these neurofilament labeled processes, as well as in areas without neurofilament labeling (Fig. 1A-D). Anti-NF labeling was only observed in regions that contained anti-vimentin labeled glia cells (Fig. 1E)..$^{\text {see also } 12}$ Antimicrotuble associated protein 2 (MAP2), a marker for dendrites, ${ }^{26}$ labeled some neurites in all 6 ERMs where it was used including PDR, PVR and iERMs. Many of the MAP2labeled process also labeled with anti-NF (Fig. 1E-G).

Anti-calretinin labeling, typically observed in retinal ganglion cells, amacrine cells, and horizontal cells, ${ }^{27-29}$ was not as common as anti-neurofilament labeling nor did it co-localize with neurofilament in the ERMs (data not shown). It was only observed in 3 out of 11 ERMs including one iERM, one NIDDM and one PDR membrane (Table 2; Fig. 2, green). The calretinin labeled processes were always observed on a bed of antivimentin labeled glia (Fig. 2, blue). Anti-SV2 labeling (Fig. 2, red) often co-localised with the anti-calretinin labeled processes. In some cases, the vesicle labeling was only observed in specific regions of the calretinin labeled processes (Fig. 2A,B). In other cases, it was observed throughout the processes appearing much more discrete than in the neurofilament-labeled neurites and often assuming a pattern that appeared vesicular or in association with "beads" along the neurites (Fig. 2C-F). 
Anti-melanopsin labeled neurites were observed in 6 out of 8 ERMs including iERM, PDR and PVR membranes (Table 2; Fig. 3, green). Generally, these processes appeared distinct from the anti-neurofilament labeled processes (Fig. 3A). In a few cases, however, there was some faint labeling of melanopsin positive neurites with antineurofilament (Fig. 3B,C; arrows). While anti-SV2 labeling was often observed in the vicinity of melanopsin labeled processes, the two typically did not co-localize (Fig. 3D). Anti-rod opsin labeled neurites were observed in 3 out of 7 ERMs including iERM, PVR and PDR membranes (Table 2; Fig. 4). These rod neurites were distinct from those neurites labeled with anti-neurofilament (Fig. 4A,B). The rod-opsin positive neurites generally co-localised with anti-synaptophysin labeling which often appeared as small uniform vesicles or in densely labeled areas which could be resolved as sites of heavy accumulation of smaller vesicles (Fig. 4C-E). The anti-rod opsin labeled neurites were often, but not always associated with anti-vimentin labeled glia (e.g. Fig. 4B).

Several of the membranes were double labeled with both anti-vimentin and antiGFAP and we observed co-localization of the two proteins, indicating that the vimentin labeling represents glial cell labeling and not dedifferentiated RPE cells (data not shown). Due to the restrictions of antibody combinations only vimentin was used to label the membranes in combination with the neuronal markers. Anti-vimentin labeling of glia was observed in all membranes where the antibody was used. As retinal astrocytes in general do not label with vimentin antibodies, and Müller cells label with both vimentin and GFAP antibodies, ${ }^{30,31}$ it is assumed that the glia labeled in the membranes are primarily Müller cells. 


\section{Discussion}

ERMs can form in eyes with no known pathology, as well as in eyes with severe retinal disruption such as RD or diabetes. Our results show that regardless of the disease condition or length of time the membrane is present in the eye, neurites are invariably observed in all membranes. Indeed, the interval between diagnosis and removal ranged from 5 weeks (PVR),to 8-12 months (iERM and PDR), and there was no apparent difference in the type of neurites or the extent of their growth. This suggests that neurite growth begins almost immediately upon formation of any ERM, following Müller cell processes, the preferred substrate for neurite growth, as they grow onto the retinal surface. The early appearance of neurites in these ERMs agrees with our studies of RD in animal models and in human ERMs where neurite sprouting occurs rapidly. ${ }^{9,12-14,32}$ In addition to neurofilament labeled neurites, we show neurites that are positive for melanopsin, calretinin and rod opsin. Many of these neurites also show labeling for the synaptic vesicle markers, synaptophysin or SV2.

Neurofilament protein is a cytoskeletal protein that is expressed in the dendrites and axons of most ganglion cells in the human retina. The expression of this protein is upregulated rapidly in a subset of ganglion cells within a few days after experimental RD of the feline retina. ${ }^{11,32}$ Within a week of RD in animal models, fine processes can be seen extending from the cell body and later growing out of the retina into ERMs. This appears to be a common phenomenon in human retina too, since neurofilament labeled neurites were observed in $100 \%$ of the ERMs examined both in this and a previous study. ${ }^{12}$ While it is not clear if these most closely resemble axons or dendrites, we did 
observe co-labeling with MAP2 in some neurites suggesting that these may form a heterogeneous mixture of processes that are dendritic and axon-like.

Calretinin is a calcium binding protein found in the cytosol of amacrine and ganglion cells in the ganglion cell layer, and amacrine and horizontal cells in the inner nuclear layer in the human retina. ${ }^{27-29}$ Importantly, the neurofilament protein antibody used in our study does not label horizontal or amacrine cells in the human retina. ${ }^{10}$ In addition, calretinin did not label the same processes as the neurofilament antibody in the ERMs, again suggesting that the neurites arise from a heterogeneous collection of neurons within the retina. Calretinin labeled processes were observed less frequently than neurofilament labeled processes and since there is no evidence for neurites growing into ERMs from amacrine cells in other studies, these data, along with that detailed above, suggest that the origin of the anti-calretinin labeled processes is most likely from a different sub-class of ganglion cell. Interestingly, the calretinin labeled neurites were consistently co-labeled with the synaptic vesicle protein, SV2.

Melanopsin is a photopigment expressed by the intrinsically photosensitive retinal ganglion cell (ipRGC) as first described by Provencio et al. ${ }^{33,34}$ The ipRGCs form part of the retino-hypothalamic tract ${ }^{35}$ and are involved in regulation of the circadian rhythm ${ }^{36,37}$ and photoentrainment. ${ }^{38}$ The ipRGC expresses melanopsin in both dendrites and axons. ${ }^{39}$ In our study the frequency of ipRGC neurites in the ERMs was relatively high despite the fact that these ganglion cells form a small minority of all the ganglion cell population. ${ }^{36,39}$ These neurites are clearly distinct from the neurofilament and calretinin labeled neurites. Although some of the melanopsin labeled neurites did show faint co-localisation with neurofilament, these processes were obviously different from those labeled brightly with 
the neurofilament antibody. It is possible that these double labeled neurites may be another subset of ipRGCs since two subpopulations of ipRGCs have been identified in mice. ${ }^{40,41}$ Our study confirms that of Vugler et al., ${ }^{6}$ using the RCS rat with retinal dystrophy, demonstrating that ipRGCs remodel during degeneration. Finally, while the ipRGCs have been shown to have synaptic vesicles at the junctions with amacrine and bipolar cells in the mouse retina, ${ }^{42}$ they do not appear to label with anti-SV2 in the ERMs.

Rod neurite sprouting was first described in vivo in the disease RP in human donor retinas where long intra retinal rod opsin positive neurites were found. ${ }^{16}$ Since then rod neurite sprouting has been described within the retinal layers in different forms of retinal dystrophy in animals models and humans..$^{2-4,13,18,21,22,43}$ These studies suggest that rod axons terminate within the inner retina as they do during development. ${ }^{44} \mathrm{We}$ show here that these neurites can continue their growth outside the retina into an ERM. The fact that rod neurites grow the entire thickness of the retina and into iERMs suggests that there need not be significant damage to photoreceptors to stimulate growth. Moreover, since vision can often return to normal after iERM removal it would appear that the extraordinary growth of rod axons has minimal effect on vision. This may not be surprising since changes in small populations of rod photoreceptors probably would not affect typical scotopic visual function. Rod opsin labeling was not observed co-localized with neurofilament since these proteins do not overlap in the retina. However, we did observe synaptophysin to be co-localised to rod neurites, an observation congruent with the presence of synaptophysin labeling in elongated rod neurites within the retina in a 
feline model of $\mathrm{RD},{ }^{43}$ the canine RP model and in human RP. ${ }^{4}{ }^{16-18}$ There is no evidence that these neurites form functional synaptic connections.

The presence of neurites is universal in ERMs, reinforcing the concept that significant disturbance of the retina is not necessary to induce the remodeling of both rod photoreceptors and ganglion cells. While it is not known what initiates neurite growth, it appears that molecules in the membranes, and in particular associated with Müller cells, may act as an attractant or stimulus for their outgrowth. Indeed, neurites in various pathologies have been shown to grow preferentially on a substrate of Müller cell glia,one of the main cellular components of ERMs. ${ }^{11,12,14,45-49}$

Although the specific protein(s) that instigates neural growth and creates the permissive environment is unknown, it has been shown that human idiopathic and diabetic ERMs express neural growth factors and receptors, such as nerve growth factor (NGF), basic fibroblast growth factor (bFGF) and glial cell line-derived growth factor (GDNF), and the receptors p75 neurotrophin receptor and tyrosine kinase receptors trkA, trkB and trkC ${ }^{50,53}$ which might be involved in neurite growth.

\section{Conclusion}

It is clear from this and other studies that adult retinal neurons retain the ability to remodel given the appropriate cues. Here we demonstrate the presence of neurites derived from rod photoreceptors as well as three sub-types of retinal ganglion cell in ERMs. This growth appears unrelated to the particular disease condition since neurites were observed in all conditions examined, irrespective of the disease being severely disruptive to the retina, as in PVR and PDR, or minimally disruptive as in iERM. Future studies are aimed at identifying factors that may be involved in initiating and guiding this 
neurite growth.

Licence for Publication

"The Corresponding Author has the right to grant on behalf of all authors and does grant on behalf of

all authors, an exclusive licence (or non exclusive for government employees) on a

worldwide basis to

the BMJ Publishing Group Ltd and its Licensees to permit this article (if accepted) to be published in $\mathrm{BJO}$

editions and any other BMJPGL products to exploit all subsidiary rights, as set out in our licence(http://group.bmj.com/products/journals/instructions-for-authors/licence-

forms/)."

Competing Interest

"Competing Interest: None to declare." 


\section{References}

1. Strettoi E, Pignatelli V. Modifications of retinal neurons in a mouse model of retinitis pigmentosa. Proc Natl Acad Sci USA 2000; 97:11020-25.

2. Jones B, Watt CB, Frederick JM, Baehr W, Chen CK, Levine EM, Milam AH, LaVail MM, Marc RE. Retinal remodeling triggered by photoreceptor degenerations. J Comp Neurol 2003; 464:1-16.

3. Jones B, Marc R. Retinal remodeling during retinal degeneration. Exp Eye Res 2005; 81:123-37.

4. Beltran W, Hammond P, Acland GM, Aguirre GD. A frameshift mutation in RPGR exon ORF15 causes photoreceptor degeneration and inner retina remodeling in a model of X-linked retinitis pigmentosa. Invest Ophthalmol Vis Sci 2006; 47:1669-81.

5. Fei Y. Cone neurite sprouting: An early onset abnormality of the cone photoreceptors in the retinal degeneration mouse. Mol Vis 2002; 8:306-14.

6. Vugler AA, Semo M, Joseph A, Jeffery G. Survival and remodeling of melanopsin cells during retinal dystrophy. Vis Neurosci 2008; 25:125-38. 
7. Meyer-Rüsenberg B, Pavlidis M, Stupp T, Thanos S. Pathological changes in human retinal ganglion cells associated with diabetic and hypertensive retinopathy. Graefes Arch Clin Exp Ophthalmol 2007; 245:1009-18.

8. Gastinger M, Kunselman AR, Conboy EE, Bronson SK, Barber AJ. Dendrite remodeling and other abnormalities in the retinal ganglion cells of Ins2Akita diabetic mice. Invest Ophthalmol Vis Sci 2008; 49:2635-42.

9. Lewis GP, Linberg KA, Fisher SK. Neurite outgrowth from bipolar and horizontal cells after experimental retinal detachment. Invest Ophthalmol Vis Sci 1998; 39:424-34.

10. Sethi CS, Lewis GP, Fisher SK, Leitner WP, Mann DL, Luthert PJ, Charteris DG. Glial remodeling and neural plasticity in human retinal detachment with PVR. Invest Ophthalmol Vis Sci 2005; 46:329-42.

11. Fisher SK, Lewis GP. Müller cell and neuronal remodeling in retinal detachment and reattachment and their potential consequences for visual recovery: a review and reconsideration of recent data. Vision Res 2003; 43:887-97.

12. Lewis GP, Betts KE, Sethi CS, Charteris DG, Lesnik Oberstein SY, Avery RL, Fisher SK. Identification of ganglion cell neurites in human subretinal and epiretinal membranes. Br J Ophthalmol 2007; 91:1234-38. 
13. Wickham L, Sethi CS, Lewis GP, Fisher SK, McLeod DC, Charteris DG. Glial and neural response in short term human retinal detachment. Arch Ophthalmol 2006; 124:1779-81.

14. Lesnik Oberstein SY, Lewis GP, Chapin EA, Fisher S.K. Ganglion cell neurites in human idiopathic epiretinal membranes. Br J Ophthalmol 2008; 92:981-85.

15. Sullivan R, Woldemussie E, Pow DV. Dendritic and synaptic plasticity of neurons in the human age related macular degeneration retina. Invest Ophthalmol Vis Sci 2007; 48:2782-91.

16. Li ZY, Kljavin IJ, Milam AH. Rod photoreceptor neurite sprouting in retinintis pigmentosa. J NeuroscI 1995; 15:5429-38.

17. Milam AH, Li ZY, Fariss RN. Histopathology of the human retina in retinitis pigmentosa. Prog Ret Eye Res 1998; 17:175-205.

18. Fariss R, Li ZY, Milam AH. Abnormalities in rod photoreceptors, amacrine cells, and horizontal cells in human retinas with retinitis pigmentosa. Am J Ophthalmol 2000; 129: 215-23.

19. Liets LC, Eliasieh K, van der List DA, Chalupa LM. Dendrites of Rod bipolar cells sprout in normal aging retina. Proc Natl Acad Sci USA 2006; 103:12156-60. 
20. Eliasieh K, Liets LC, Chalupa LM. Cellular reorganisation in the human retina during normal aging. Invest Ophthalmol Vis Sci 2007; 48:2824-30.

21. Marc RE, Jones BW, Watt CB, Strettoi E. Neural remodeling in retinal degeneration. Prog Ret Eye Res 2003; 22:607-655.

22. Fisher SK, Lewis, GP, Linberg KA, Verardo MR. Cellular remodeling in mammalian retina: results from studies of experimental retinal detachment. Prog Ret Eye Res 2005; 24:395-431.

23. Hiscott PS, Grierson I, McLeod D. Natural history of fibrocellular epiretinal membranes: a quantative, audioradiographic and immunohistochemical study. $\mathrm{Br} J$ Ophthalmol 1985; 69:810-23.

24. Hui YN, Goodnight R, Zhang XJ, Sorgente N, Ryan SJ. Glial epiretinal membranes and contraction. Immunohistochemical and morphological studies. Arch Ophthalmol 1988; 106:1280-85.

25. Guerin CJ, Wolfshagen RW, Eifrig DE, Anderson DH. Immunocytochemical identification of Müller's cell glia as a component of human epiretinal membranes. Invest Ophthalmol Vis Sci 1990; 31:1483-91. 
26. Bernhardt R, Matus A. Light and electron microscopic studies of the distribution of microtubule-associated protein 2 in rat brain: a difference between dendritic and axonal cytoskeletons. J Comp Neurol 1984; 226:203-21.

27. Goebel D, Pourcho R. Calretinin in the cat retina: Colocalisations with other calcium binding proteins, GABA and glycine. Vis Neurosci 1997; 14:311-322.

28. Nag TC, Wadhwa S. Developmental expression of calretinin immunoreactivity in the human retina and a comparison with two other EF hand calcium binding proteins. Neuroscience 1999; 91:41-50.

29. Linberg K, Lewis GP, Matsumoto B, Fisher SK. Immunocytochemical evidence that rod connected horizontal cell axon terminals remodel in response to experimental retinal detachment in the cat. Mol Vis 2006; 12:1674-86.

30. Lewis GP, Matsumoto B, Fisher SK. Changes in the organization and expression of cytoskeletal proteins during retinal degeneration induced by retinal detachment. Invest Ophthalmol Vis Sci 1995; 36:2404-16.

31. Lewis GP, Fisher SK. Up-regulation of glial fibrillary acidic protein in response to retinal injury: its potential role in glial remodeling and a comparison to vimentin 
expression. Int Rev Cytol 2003; 230:263-90.

32. Coblentz FE, Radeke MJ, Lewis GP, Fisher SK. Evidence that ganglion cells react to retinal detachment. Exp Eye Res 2003; 76:333-42.

33. Provencio I, Jiang G, De Grip WJ, Hayes WP, Rollag MD. Melanopsin: an opsin in melanophores, brain and eye. Proc Natl Acad Sci USA 1998; 95:340-45.

34. Provencio I, Rodriguez IR, Jiang G, Hayes WP, Moreira EF, Rollag MD. A novel human opsin in the inner retina. J Neurosci 2000; 20:600-5.

35. Gooley J, Lu J, Chou TC, Scammell TE, Saper CB. Melanopsin in cells of origin of the retinohypothalamic tract. Nat Neurosci 2001; 4:1165.

36. Berson D., Dunn FA, Takao M. Phototransduction by retinal ganglion cells that set the circadian clock. Science 2002; 295:1070-73.

37. Hannibal J, Hindersson P, Knudsen SM, Georg B, Fahrenkrug J. The photopigment melanopsin is exclusively present in pituitary adenylate cyclise-activating polypeptide containing retinal ganglion cells of the retinohypothalamic tract. J Neurosci 2002; 22: RC191 (1-7). 
38. Rollag M, Berson DM, Provencio I. Melanopsin, ganglion cell photoreceptors, and mammalian photoentrainment. J Biol Rhythms 2003; 18:227-34.

39. Hattar S, Liao HW, Takao M, Berson DM, Yau KW. Melanopsin-containing retinal ganglion cells: architecture, projections, and intrinsic photosensitivity. Science 2002; 295:1065-70.

40. Baver SB, Pickard GE, Sollars PJ, Pickard GE. Two types of melanopsin retinal ganglion cell differentially innervate the hypothalamic suprachiasmatic nucleus and the olivary pretectal nucleus. Eur J Neurosci 2008; 27:1763-70.

41. Schmidt TM, Kofuji P. Functional and morphological differences among intrinsically photosensitive retinal ganglion cells. J Neurosci 2009; 29:476-82.

42. Belenky M, Smeraski CA, Provencio I, Sollars PJ, Pickard GE. Melanopsin retinal ganglion cells receive bipolar and amacrine cell synapses. J Comp Neurol 2003; 460:38093.

43. Lewis GP, Sethi CS, Linberg KA, Charteris DG, Fisher SK. Experimental retinal reattachment: a new perspective. Mol Neurobiol 2003; 28:159-75.

44. Johnson PT, Williams RR, Cusato K, Reese BE. Rods and cones project to the inner plexiform layer during development. J Comp Neurol 1999; 414:1-12. 
45. Jerdan JA, Pepose JS, Michels RG, Hayashi H, de Bustros S, Sebag M, Glaser BM. Proliferative vitreoretinopathy membranes. An immunohistochemical study. Ophthalmology 1989; 96:801-10.

46. Morino I, Hiscott P, McKechnie N, Grierson I. Variation in epiretinal membrane components with clinical duration of proliferative tissue. Br J Ophthalmol 1990; 74:39399.

47. Vinores SA, Campochiaro PA, Conway BP. Ultrastructural and electronimmunocytochemical characterization of cells in epiretinal membranes. Invest Ophthalmol Vis Sci 1990; 31:14-28.

48. Heidenkummer HP, Kampik A. Proliferative activity and immunohistochemical cell differentiation in human epiretinal membranes. Ger J Ophthalmol 1992; 1:170-75.

49. Heidenkummer HP, Kampik A, Petrovski B. Proliferative activity in epiretinal membranes. The use of the monoclonal antibody Ki-67 in proliferative vitreoretinal diseases. Retina 1992; 12:52-58.

50. Harada T, Harada C, Mitamura Y, Akazawa C, Ohtsuka K, Ohno S, Takeuchi S, Wada K. Neurotrophic factor receptors in epiretinal membranes after human diabetic retinopathy. Diabetes Care 2002; 25:1060-65. 
51. Mitamura $Y$, Harada $C$, Harada T. Role of cytokines and trophic factors in the pathogenesis of diabetic retinopathy. Curr Diabetes Rev 2005; 1:73-81.

52. Harada C, Mitamura Y, Harada T. The role of cytokines and trophic factors in epiretinal membranes: involvement of signal transduction in glial cells. Prog Ret Eye Res 2006; 25:149-64.

53. Minchiotti S, Stampachiacchiere B, Micera A, Lambiase A, Ripandelli G, Billi B, Bonini S. Human idiopathic epiretinal membranes express NGF and NGF receptors. Retina 2008; 28:628-37. 
Table 1. Antibodies used for the study along with their source and concentrations.

Table 2. The antibody combinations used on different membrane types and whether the labeling was present (+) or absent (-). (“+/-“= positive but light staining.)

Figure 1. Confocal micrographs of epiretinal membranes labeled with anti-neurofilament protein (red; A-F), anti-synaptophysin (blue; A-D), anti-vimentin (green; E) and antiMAP2 (blue; E-G). In some cases, anti-synaptophysin labeling appears to overlap with the neurofilament labeled processes (A-C). The labeling that does not overlap with neurofilament presumably would be present in a different population of neurites. MAP2 labeling overlaps with some neurofilament labeled processes (E-G). The close association between anti-neurofilament, and anti-MAP2 labeled neurites with anti-vimentin labeled glia produces the appearance of yellow $($ red + green $)$ or white $($ red + green + blue $)$ labeling of the long neurites in "E" (E-F are the same image with different color combinations). Figure "B" is the same as "A" with the red channel turned off. A-C \& EG are from iERMs; D is from PDR. Scale bars: A-C \& E-G, 50 $\mu$ m; D, $20 \mu \mathrm{m}$.

Figure 2. Confocal micrographs of epiretinal membranes labeled with anti-calretinin (green), anti-SV2 (red), and anti-vimentin (blue). Anti-calretinin labeled processes can appear tortuous $(\mathrm{A}, \mathrm{B})$ or beaded $(\mathrm{C}-\mathrm{F})$ but invariably contain at least some anti-SV2 labeling. Figures "B" and "D" are the same as "A" and " $C$ " with the green channel turned off. Figure " $F$ " is the same as "E" with the red channel turned off. A\&B are from PDR; 


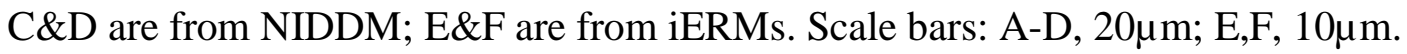

Figure 3. Confocal micrographs of epiretinal membranes labeled with anti-melanopsin (green; A-D), anti-neurofilament (red; A-C), and anti-SV2 (red; D). Melanopsin positive processes appear to intermingle with neurofilament positive processes (A-C) although faint neurofilament labeling can be observed in some melanopsin labeled neurites when the green channel is removed (C; arrows). Anti-SV2 labeling appears in the vicinity of melanopsin labeled processes although the two typically did not co-localize. A is from

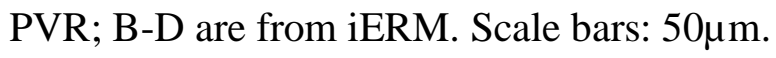

Figure 4. Confocal micrographs of epiretinal membranes labeled with anti-rod opsin (green; A-D), anti-neurofilament (red; A,B), anti-synaptophysin (red; C-E) and antivmentin (blue; A-E). Anti-rod opsin labeling does not overlap with neurofilament protein $(A, B)$ but does overlap with anti-synaptophsyin labeling (C-E). Some synaptophysin labeling can be observed away from the rod opsin labeling indicating the presence of other neuronal cell types not labeled for here. Figure "D" is a higher magnification of "C"; Figure "E" is the same as Figure "D" with the green channel turned off. All images are from iERMs. Scale bars: A,B, 50 $\mu$ m; C, $20 \mu \mathrm{m} ; \mathrm{D}, \mathrm{E}, 10 \mu \mathrm{m}$. 
$\mathrm{NF}=$ red;Synaptophysin=blue

Synaptophysin=blue

A

$\mathrm{NF}=$ red;Synaptophysin=blue

NF=red;Synaptophysin=blue

D

NE=red Map $2=$ blue Vimentin $=$ green

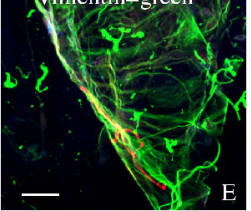

$\mathrm{NF}=$ red; Map2=blue

Map2=blue 
Calretinin=green; SV2=red

Vimentin=blue

Calretinin=green; SV2=red

SV2=red; Vimentin=blue Vimentin=blue

Calretinin $=$ green: $S$ V $2=$ red Vimentin=blue 
Melanopsin=green; $\mathrm{NF}=$ red

A

Melanopsin=green; $\mathrm{NF}=$ red

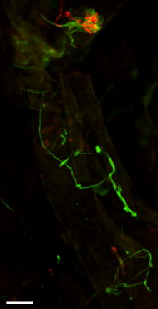

$\mathrm{NF}=$ red
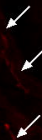

Melanopsin=green;

sSV2=red

C

D 


\section{Rod opsin=green;}

$\mathrm{NF}=\mathrm{red}$

Vimient in=blue
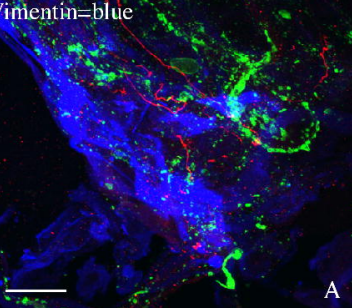

Rod opsin=green;

$\mathrm{NF}=$ red;

Vimentin=blue
Rod opsin=green;
Synaptophysin=re
Vimentin=blue

Rod opsin=green;
Synaptophysin=red;
Vimentin=blue

Rod opsin=gree
Synaptophysin=
Vimentin=blue
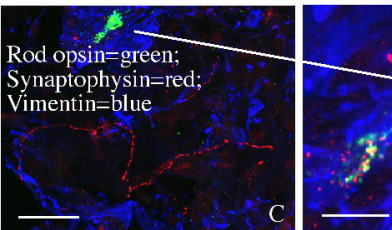

D 


\begin{tabular}{|l|l|l|l|}
\hline Antibody & species & Conc. & Source \\
\hline Neurofilament protein & mouse & $1: 500$ & Biomeda, Hayward CA \\
\hline Melanopsin & rabbit & $1: 400$ & Affinity BioReagents, Golden CO \\
\hline Calretinin & rabbit & $1: 500$ & Chemicon, Temecula CA \\
\hline Rod Opsin (rho 4D2) & mouse & $1: 100$ & Robert Molday, UBC \\
\hline Synaptophysin & rabbit & $1: 100$ & Dako, Carpinteria CA \\
\hline SV2 & mouse & $1: 250$ & DSHB, Iowa City IA \\
\hline Vimentin & chicken & $1: 2000$ & Chemicon, Temecula CA \\
\hline Map 2 & mouse & $1: 100$ & Sigma, St. Louis MO \\
\hline Hoechst & & $1: 5000$ & Invitrogen, Carlsbad CA \\
\hline $\begin{array}{l}\text { Secondaries: Donkey anti- } \\
\text { CY-2, -3, -5 }\end{array}$ & & $1: 200$ & $\begin{array}{l}\text { Jackson ImmunoReserach, } \\
\text { West Grove, PA }\end{array}$ \\
\hline
\end{tabular}




\begin{tabular}{|c|c|c|c|c|c|c|c|c|}
\hline Study & ERM type & $\mathrm{NF}$ & calretinin & melanopsin & rod & \begin{tabular}{|l|} 
Synap or \\
SV2
\end{tabular} & $\operatorname{vim}$ & $\begin{array}{l}\text { map } \\
\text { II }\end{array}$ \\
\hline \multirow[t]{6}{*}{ Synaptoph+NF } & PVR5 & + & & & & + & & \\
\hline & PVR16 & + & & & & + & & \\
\hline & PDR1 & + & & & & + & & \\
\hline & PDR6 & + & & & & + & & \\
\hline & iERM2 & + & & & & + & & \\
\hline & iERM4 & + & & & & + & & \\
\hline \multirow{6}{*}{ Calretinin+NF } & iERM16 & + & - & & & & & \\
\hline & iERM15 & + & - & & & & & \\
\hline & PVR17a & + & - & & & & & \\
\hline & PVR12b & + & - & & & & & \\
\hline & PVR9 & + & - & & & & & \\
\hline & PVR11 & + & - & & & & & \\
\hline \multirow[t]{6}{*}{ Rod opsin+synaptoph+vim } & iERM1 & & & & - & + & + & \\
\hline & iERM8 & & & & - & + & + & \\
\hline & PVR1 & & & & + & + & + & \\
\hline & PDR1 & & & & + & + & + & \\
\hline & PDR2 & & & & - & + & + & \\
\hline & Niddm1 & & & & - & + & + & \\
\hline \multirow[t]{5}{*}{ Calretinin+SV2+vim } & iERM2 & & - & & & - & + & \\
\hline & iERM5 & & + & & & + & + & \\
\hline & PVR2 & & - & & & - & + & \\
\hline & PDR1 & & + & & & + & + & \\
\hline & Niddm2 & & + & & & + & + & \\
\hline \multirow{5}{*}{ Melanopsin+NF+vim } & iERM3 & $+/-$ & & + & & & + & \\
\hline & iERM6 & $+/-$ & & + & & & + & \\
\hline & PVR3 & $+/-$ & & + & & & + & \\
\hline & Niddm3 & $+/-$ & & - & & & + & \\
\hline & PDR1 & $+/-$ & & + & & & + & \\
\hline \multirow[t]{3}{*}{ Melanopsin+SV2+vim } & iERM7 & & & + & & + & + & \\
\hline & PVR4 & & & - & & - & + & \\
\hline & PDR1 & & & + & & - & + & \\
\hline \multirow[t]{8}{*}{ NF+synaptoph } & PDR2a & + & & & & + & & \\
\hline & PDR5a & + & & & & + & & \\
\hline & PDR7a & + & & & & + & & \\
\hline & PVR2a & + & & & & + & & \\
\hline & PVR4a & + & & & & + & & \\
\hline & iERM8a & + & & & & + & & \\
\hline & iERM9a & + & & & & + & & \\
\hline & iERM17 & + & & & & + & & \\
\hline \multirow{6}{*}{ MAPII+NF+vim } & PVR12 & + & & & & & + & + \\
\hline & PVR21 & + & & & & & + & + \\
\hline & PDR2 & + & & & & & + & + \\
\hline & PDR7c & + & & & & & + & + \\
\hline & iERM11 & + & & & & & + & + \\
\hline & iERM13 & + & & & & & + & + \\
\hline Rod opsin+vim & iERM5 & & & & + & & + & \\
\hline
\end{tabular}

